\title{
Representative claims and expected gains. Minority council elections and intra-ethnic competition in Serbia
}

\author{
Christina Isabel Zuber ${ }^{\mathrm{a} *}$ and Jan Jakub Muśr \\ ${ }^{a}$ Department of Political Science, University of Cologne, Gottfried-Keller-Str. 1, Cologne 50870, \\ Germany; ${ }^{b}$ Department of Political Science, School of Social Sciences and Humanities, Catholic \\ University of Lublin, Al. Ractawickie 14, Lublin 20-950, Poland
}

\begin{abstract}
This article examines the first direct elections to minority councils in Serbia. It seeks to build hypotheses on the interplay between minority council elections and the overall patterns of intraethnic party competition in divided societies. Following an introduction to minority politics in Serbia, the authors analyse the campaign for the Bosniak and the Hungarian minority council. Evidence from field research suggests that minority council elections reflect the situation of intra-ethnic competition and provide an additional arena for ethnic outbidding for new ethnic parties.
\end{abstract}

Keywords: cultural autonomy; minority councils; intra-ethnic competition; Serbia

\section{Introduction}

In democracies characterised by a cleavage that divides the population into a national majority and one or more national minorities, institutional autonomy solutions are often advocated to avoid permanent majority domination and provide minorities with a possibility of self-governing their affairs to some extent (Lijphart 1977; Sisk 1996). Academic debate has predominantly centred on the territorially based model of minority self-government in the form of asymmetrical, or ethno-federalism (Kymlicka 1998; Agranoff 1999; Zuber 2011a). Lijphart himself, however, pointed out that: "federalism is merely one way of establishing segmental autonomy. When the segments of a plural society are geographically intermixed, segmental autonomy can be instituted in the form of autonomous cultural councils and educational associations" (Lijphart 1989, 40). Cultural autonomy exercised through minority councils separates ethnically defined policy areas concerning "the cultural, linguistic, ethnic, or religious matters of a minority group" (Stroschein 2003, 10) from policy areas affecting all citizens alike. The idea of granting national-cultural autonomy on a personal rather than territorial basis can be traced back to debates in Imperial Austria and was originally developed in the writings of the Austro-Marxists Karl Renner and Otto Bauer (Nimni 1999). In both the historical and the contemporary debate, cultural self-government has been praised for providing ethnic groups with a means to self-determination in policy areas that are particularly relevant for preserving their ethno-cultural identity, while avoiding the incentives for separatism that are commonly associated with territorial solutions (Bieber 1999, 91; Stroschein 2003, 10; Nimni 2007). On normative grounds, however, scholars have warned that granting cultural group rights through minority councils may threaten norms of equality and individual rights at the within-group level (Deets and Stroschein 2005).

*Corresponding author. Email: zuberc@uni-koeln.de 
According to Article 2 of the Serbian Law on National Councils of National Minorities, "a national minority shall be represented by its national council in the field of education, culture, information in the language of a national minority as well as in the official use of language and script". The first direct elections to national minority councils (NMCs) in Serbia took place on 6 June 2010. In most of the 16 minority communities that elected their council members on 6 June 2010 , several minority organisations fielded electoral lists, thereby engaging in intra-ethnic competition over who could best represent the minority group within its council. This represents a puzzle for the field of ethnic politics, where scholars still tend to make "the routine assumption that members of ethnic groups 'naturally' mass behind ethnic organizations" (Chandra 2011, 153, original hyphenation). In line with this general tendency, political scientists have so far tended to evade the question of who seeks to represent minorities in their cultural councils (with the notable exception of Vermeersch 2010). This article seeks to fill this gap through an explorative analysis of intra-ethnic competition for minority council offices in Serbia. Intraethnic competition indicates that it is not clear who best represents the interests of a minority in the multi-national state.

Given the competencies of the NMCs, intra-ethnic competition should ideally resemble competition over the best policy proposals in fields where minority councils represent the minority according to the law - education, culture, media, and language use. However, in environments where ethnic cleavages are politically salient, minority council elections do not take place in isolation but are embedded within the general pattern of intra-ethnic political competition for ethnic votes. This article therefore argues that - contrary to their legal limitation on policy areas important for a minority's cultural self-determination - minority council elections in divided societies are affected by the given pattern of political competition for minority votes and may therefore be used as an additional arena for ethnic outbidding (Rabushka and Shepsle 1972; Horowitz 1985).

The recent introduction of direct elections in the Serbian case provides favourable conditions to probe the plausibility of the argument that minority council elections reflect the overall pattern of intra-ethnic competition in ethnically divided societies. To this aim, the article is structured as follows. Section 2 lays out the legal provisions for the representation and participation of national minorities in Serbian politics, and provides an overview on the NMC elections of 6 June 2010. In Section 3, we introduce the two cases selected for analysis, the campaign for the Bosniak and the Hungarian council. Section 4 explores the argument that competition for office in minority councils mirrors political competition for minority votes more generally on the basis of evidence from semi-structured interviews with Hungarian and Bosniak minority elites that were conducted during field research at the time of the electoral campaign for the NMCs. The analysis shows how political parties used the minority council election as an additional platform within the wider game of political competition for ethnic minority votes. ${ }^{1}$ The last section concludes.

\section{Legal standards of minority protection in Serbia and the minority council elections of 6 June 2010}

Three significant international bodies supplement and, to some degree, reinforce each other in the area of protecting minority rights in Europe. These are: the Organization for Security and Cooperation in Europe, the Council of Europe, and the European Union (hereafter EU). The process of Serbia's integration into the EU constitutes one of the strongest incentives for reform in the country. Therefore, of those three, the last can be considered the most influential. The European Council concluded in Copenhagen that EU "membership requires that the candidate country has achieved stability of institutions, and guaranteeing democracy, the rule of law, human rights and respect for and protection of minorities" (European Council 1993, 13). That means that as a potential candidate for EU membership, Serbia is facing the requirement to 
respect minority rights among other criteria for accession. ${ }^{2}$ In 2001, Serbia joined the Framework Convention for the Protection of National Minorities, and the Law on Protection of Rights and Freedoms of National Minorities regulating the status of national minorities was subsequently introduced in 2002 (Gojković 2009, 5-6). The 2006 Constitution of the Republic of Serbia guarantees a range of rights of national minorities, including the right to local self-government and provincial autonomy (Article 12 of the Constitution) and "special protection [...] for the purpose of exercising full equality and preserving their identity" (Article 14 of the Constitution), which are followed by Charter II of the Constitution that deals with "Human and Minority Rights and Freedoms" (Articles 18-81 of the Constitution). Especially important with regard to the topic of this article are article 79 ("right to preservation of specificity") and article 80 ("right to association and cooperation with compatriots"), guaranteeing that national minorities can preserve their ethno-cultural distinctiveness through their own educational and cultural associations.

These rights made an important step towards being implemented in political practice when the Serbian parliament adopted the Law on National Councils of National Minorities (in Serbian: Zakon o Nacionalnim Savetima Nacionalnih Manjina, hereafter the Law on National Councils) in 2009. ${ }^{3}$ The Law on National Councils provides national minorities in Serbia with an institutional body through which they can exercise the right to preserve their ethno-cultural specificity. The model differs significantly from those adopted by neighbouring Bosnia and Herzegovina, Macedonia, or Kosovo as it does not realise minority protection within an overall consociational power-sharing regime at the central level of state governance. ${ }^{4}$ Rather, it tends to keep ethnic questions at the local level, away from the state-level institutions.

The Serbian law-makers adopted solutions that seem to be narrow at first glance, as far as responsibilities and rights of the NMCs are concerned. The 2009 Law on National Councils indicates that the National Councils of National Minorities (hereafter NMCs) represent their respective national minorities in the four areas of education, culture, information in the national minority's language, and official use of the minority language and script. Though narrowly defined, these are areas that can be expected to fall into the direct interest of members of national minorities. Education, culture, and language use enable an ethnic group to preserve and foster its identity and thus to secure its ethno-cultural persistence. The detailed competencies of the councils in these four areas are defined in Articles 10-24 of the Law on National Councils. In the following sections, we will focus on presenting competencies in the area of information in the minority language, since they provide the institutional channel through which minority councils can exercise influence on the coverage of electoral campaigns.

In the field of minority media, NMCs may "independently or in co-operation with another legal entity, establish the institutions and business organisations to perform the activities of newspaper-publishing and radio-television broadcasting, printing and reproduction of the recorded media and exercise the rights and obligations of the founder" (Article 19 of the Law on National Councils). However, minority councils do not only have the right to establish their own minority media outlets, they also participate in the institutional management of any minority language broadcast of Radio Television Serbia. For example, NMCs set the criteria for selecting editorsin-chief of all broadcasts in the minority language of Radio Television Serbia and propose candidates for this position (Article 20 of the Law on National Councils). The competencies are not limited to staff nomination and selection: NMCs may additionally adopt broadcasting strategies; suggest how to distribute resources from public budgets to broadcasting companies; and last but not least, directly influence what is being broadcasted by giving "suggestions and recommendations regarding the programmes broadcasted in the language of a national minority" (Article 21 of the Law on National Councils).

Beyond their key direct competencies in the four areas of culture, education, information, and use of language and script, NMCs in Serbia also participate in the decision-making process at the 
local and state levels if minority rights are concerned. They may submit proposals, initiatives, and opinions to the state bodies, the bodies of the autonomous province of Vojvodina, and to the local self-government units, and their opinion shall be sought before decisions are made that touch upon minority rights and the areas of competence of the minority councils (Article 25 and 26 of the Law on National Councils). Ultimately:

a national council may submit an initiative to the Government to repeal, i.e. to quash the regulations of the state bodies and special organisations, which are not in compliance with the provisions of this law [the law on National Councils, authors' note] and other laws and regulations related to national minorities. (Article 25 of the Law on National Councils)

As leverage to be used against local or state authorities, NMCs can bring a case to the Constitutional Court, the Ombudsman, and to other institutions responsible for the protection of minority rights in Serbia. NMCs in Serbia can therefore have a significant impact on education, culture, information policy (media), and use of language and script at the local level and are able, according to the legal solutions adopted, to influence local self-government.

According to the Law on National Councils, the financial means for the activities of the Serbian NMCs are secured from the state, provincial and local budgets, donations, and other revenue, as regulated by Articles $112-119$ of the Law on National Councils. NMC members are allowed to be paid for their work (Article 113 of the Law on National Councils).

The Law on National Councils states in Article 29 that minority council members can either be directly elected by individuals who self-identify with the minority in question or can be elected by delegated electors who convene in an electoral assembly. A special condition for direct election applies: direct elections are possible if more than $50 \%$ of all members of a national minority (according to the results of the last census minus 20\%) register in advance on a special register of minority voters. Article 45 of the Law on National Councils states that:

any citizen having a voting right, a member of the national minority [...] may request in writing in a special form to be entered into a separate register of voters of a national minority concerned within 15 days from the date of the submission of the request.

The register of voters therefore serves: (1) to establish whether the minority as a group is entitled to vote directly and (2) to define who is eligible to vote, since only pre-registered voters are. Unlike in general elections, the lists of voters are not compiled by the state authorities. Instead, individuals who identify with a minority need to themselves request and fill in the form to be listed in the register of those eligible to vote. This provides an opportunity for minority organisations to support the registration process by collecting forms en bloc. If a minority does not fulfil the condition for direct elections, council members are elected by an "assembly of electors" (in Serbian: elektorska skupština). Electors are either delegated by a minority organisation ${ }^{5}$ or have collected the signatures of at least 100 individual minority members (for more details, see Article $100 \mathrm{ff}$. of the Law on National Councils). This system was already in place before the 2009 Law introduced the option of direct elections.

Finally, a list of candidates for the council may be submitted by a group of minority members, a minority association, and/or a political organization representing a minority group (Articles 62 and 71 of the Law on National Councils). Article 71 states:

Under the conditions prescribed by this law, electoral lists may be proposed by a group of voters entered into the special register of voters of a national minority concerned, namely by organizations, associations of citizens, as well as by political organization of a national minority concerned. 
Since ethnic minority parties are political organisations representing minority groups, they can field candidates and enter competitions for representing the minority within the council. These candidates' lists have to be signed by at least $1 \%$ of the pre-registered members of the relevant minority (with at least 50 signatures in absolute terms) if the electoral list is to be accepted by the Central Election Commission of Serbia.

Most of the 19 constitutionally recognised minorities that elected their representatives on 6 June 2010 fulfilled the legal requirement for direct elections. Only the Croatian, Macedonian, and Slovenian minorities did not qualify for direct vote and elected their representatives through an assembly of electors. Sixteen minority councils were directly elected: Greek, Bulgarian, German, Ukrainian, Bosniak, Albanian, Rusyn, Hungarian, Roma, Romanian, Slovak, Vlach, Czech, Egyptian, Bunjevac, and Ashkali NMCs.

The intensity of competition varied significantly between the different minority communities. The Czech minority only had one choice, the list "Czechs together" (in Serbian: Česi zajedno) that consequently received $100 \%$ of Czech minority votes. Two lists stood for elections to the Albanian, Greek, Egyptian and German NMCs, three for the Bosniak and the Ashkali, five for the Hungarian and Slovak, six for the Rusyn and Romanian, seven for the Ukrainian, Bulgarian and Bunjevac, and nine for the Vlach. The campaign for the Roma NMC witnessed the maximum of 10 lists (Ministry of Human and Minority Rights 2010, for a complete overview on all elections see the appendix of this article).

\section{The NMC elections within the Hungarian and the Bosniak community}

The existence of intra-ethnic competition between different electoral lists in all but one of the 16 individual NMC elections suggests a closer look at how direct elections to minority councils are affected by the patterns of intra-ethnic competition for ethnic minority votes more generally. For an exploration of this argument, we focus on the minority councils of the two largest national minorities in Serbia: Hungarians in Vojvodina and Bosniaks in Sandžak. The rationale behind selecting these two minority groups is that they constitute typical cases regarding the level of intraethnic competition for minority council representation within Serbia. The two groups displayed levels of contestation of five lists (Hungarians) and three lists (Bosniaks). The average in the population of 16 minority council elections in Serbia was 4.8 competing organisations per minority community (for the complete distribution of the number of competing organisations, see the appendix). Typical cases are suitable for case studies used for hypothesis formation, given that generalisation is the underlying research goal, since a typical case has the largest number of similar cases in the population (Rohlfing 2012, 66-70).

Vojvodina, the "fatherland" of Serbian Hungarians, used to belong to the Kingdom of Hungary for centuries and became a part of Yugoslavia only after World War I. Today, Hungarians constitute a significant minority in Vojvodina. The share of Hungarians in the autonomous province of Vojvodina is $14.3 \%$ and the share of Hungarians in the whole Republic of Serbia is 3.9\% (293,299 Hungarians in total) according to the 2002 census (Republika Srbija - Republički zavod za statistiku 2003). There are many reasons why Hungarians have not become the majority in these lands. Vojvodina became an asylum for Serbs fleeing from other territories since the seventeenth century. Also, during the fall of Yugoslavia in 1990s, many Croatian and Bosnian Serbs fled to Vojvodina. In 1948, for example, Hungarians amounted to one-fourth of the Vojvodina population and made up 7.5\% of the Republic of Serbia. Having moved from the mountainous and rocky hills of Southern Serbia, Kosovo, Bosnia, Krajina, or Herzegovina to the fertile lands north of Belgrade did not motivate visitors to leave their new homes again (Kocsis and Kocsisné Hodosi 1998; Eberhardt 2003). Combined with migration away from Vojvodina to Hungary over the past years, the actual number of Hungarians in Serbia in 2010 is nowadays considered to be even smaller than the 2002 census suggests. ${ }^{6}$ 
At the time of the elections to the minority councils, five parties were registered as Hungarian minority parties in Serbia (Ministry for Public Administration and Local Self Government n.d.). The largest party, the Alliance of Vojvodina Hungarians (Savez vojvođanskih Mađara, hereafter SVM), is the only Hungarian party that holds seats in the current Serbian parliament. The oldest party, the Democratic Community of Vojvodina Hungarians (Demokratska zajednica vojvođanskih Mađara, hereafter DZVM) and its splinter, the Democratic Party of Vojvodina Hungarians (Demokratska stranka vojvođanskih Mađara, hereafter DSVM), as well as the Civic Union of Hungarians (Građanski savez Mađara, GSM) are marginal players at the national level but retain local support bases. The Movement of Hungarian Hope (Pokret mađarske nade, PMN) was founded not long before the minority council elections. Vojvodina Hungarians participate in contemporary Serbian politics not only through this range of ethnic minority parties, but also tend to support civic parties such as the Democratic Party (Demokratska stranka, hereafter DS) and the regionalist League of Social Democrats of Vojvodina (Liga Socijaldemokrata Vojvodine, hereafter LSV). LSV defends the interests of the multi-ethnic region of Vojvodina against the central state. Hungarians also constitute a minority within the region of Vojvodina and ethnic Hungarian parties (in particular DZVM and GSM, and more recently also PMN) have traditionally focused on ethno-territorial autonomy for the Northern part of Vojvodina (Severna Bačka) where Hungarians live territorially concentrated and consider the question of autonomy for the entire province of Vojvodina to be a Serbian issue. However, LSV has always adopted a very minority-friendly stance and advocates a multi-ethnic Vojvodina with peacefully co-existing ethnic groups. According to a Hungarian journalist, the party has therefore traditionally constituted an attractive choice for ethnic Hungarian voters. ${ }^{7}$

Almost all of Serbia's Bosniaks live in Southern Serbia in a region commonly referred to as the Serbian part of Sandžak, bordering with the Montenegrin Sandžak to the south. ${ }^{8}$ Both Sandžaks, the Serbian and the Montenegrin, are inhabited by Slav Muslims, who identify themselves as Bosniaks. The region of Sandžak also links Bosnian Muslims and Kosovo Muslims. Sandžak Bosniaks are Slavs, who converted to Islam during the Ottoman rule in the Balkans. After the Balkan wars, during the turbulent first half of the twentieth century, many of them fled to Turkey. Today Bosniaks and Muslims by nationality together amount to $2.1 \%$ of the Serbian population, corresponding to a total number of slightly over 155,000 (Republika Srbija Republički zavod za statistiku 2003). ${ }^{9}$

At the time of the elections to the NMCs, ten parties were registered as Bosniak minority parties (Ministry for Public Administration and Local Self Government n.d.). Of these, the most significant forces at the time of the elections were the Sandžak Democratic Party (Sandžačka demokratska partija, SDP) and the Bosniak list for a European Sandžak (Bošnjačka lista za evropski Sandžak), a permanent electoral coalition headed by the Party for Democratic Action of Sandžak (Stranka demokratske akcije Sandžaka, SDA). A newcomer also participated in the minority council elections, the Sandžak People's Party (Sandžačka narodna partija, SNP), whose leader, Mirsad Đerlek, is a former member of SDP.

\section{How minority council elections are turned into an additional arena for intra-ethnic party competition}

The following section shows how minority council elections reflect the overall pattern of political competition for Bosniak and Hungarian minority votes in Serbia, both in terms of the participating actors and in terms of their campaigns. Those political parties which compete for minority votes in contests for the main democratic offices also dominated the contest for the Bosniak and Hungarian minority council. Furthermore, the representative claims made by these parties during the campaign show that the minority council elections provided an additional arena for ethnic outbidding, 
particularly for a new organisation in the Bosniak arena. The ethnic outbidding model of party competition in divided societies (Rabushka and Shepsle 1972; Horowitz 1985) expects that if the electoral market is fully segmented along ethnic lines, ethnic parties will seek to maximise their votes by adopting more radical positions than their competitors. Recent contributions have challenged the ethnic outbidding model and have emphasised alternative strategies of ethnic parties (Chandra 2005; Zuber 2011b). However, NMC elections take place only among the minority electorate and therefore in an ethnically perfectly segmented electoral market where ethnic outbidding is potentially more rewarding than in competition for other democratic offices, where minority ethnic issues constitute only one among a range of salient campaign topics, and where civic parties try to de-segment the market appealing to voters across ethnic divides.

\subsection{NMC elections and political parties}

Some of the lists of candidates for the elections to both the Bosniak and Hungarian minority councils were fielded with a focus on granting key positions to cultural and academic elites from among the minority community, yet political parties dominated the elections nonetheless, either by fielding an official party list directly, or by openly supporting a list that appeared to be prima facie non-partisan. In the latter case, however, the affiliations with parties were publicly known, since party leaders were at the front line of rallying support for the list they promoted. This strategy was not limited to ethnic minority parties but was also applied by non-ethnic parties with a civic orientation that successfully gain minority votes in general political elections: Besides minority parties, the DS led by Boris Tadić, the Liberal-Democratic Party (LDP) led by Cedomir Jovanović, and as an additional regionalist player in Vojvodina, the LSV, headed by Nenad Čanak, decided to enter the minority council elections.

Of the five Hungarian lists for the NMC elections of 6 June, one was fielded and supported by an ethnic minority party, the PMN (Table 1). The other four lists were officially fielded by citizens' associations but were supported by political parties, carried similar names as those parties, and included party members. Two Hungarian minority parties did not present or support a list for the NMC elections of 6 June 2010: DSVM and DZVM. The other three parties that are registered as Hungarian minority parties did participate: the newest Hungarian party, the PMN with its own list carrying the same name as the party; the largest Hungarian minority party, SVM, by supporting a list that consisted of both party members and non-party members; and finally, Laszlo Rac Szabo, the leader of GSM by fielding a list together with a former member of SVM, Zoltan Bunjik. Two lists were supported by non-ethnic parties, DS and LSV.

In the Bosniak case, all three lists were officially fielded by non-political minority associations but again prominently supported by political parties. The two dominant Bosniak minority parties at the time, the SDP and the Bosniak list for a European Sandžak (a permanent electoral coalition of three Bosniak parties headed by SDA), each chose to support one list for the NMC elections (Table 1). The third list was fielded by a civic organisation, the Bosniak Cultural Community (Bošnjačka Kulturna Zajednica, BKZ). The BKZ list was headed by Muamer Zukorlić, the religious leader of the Islamic community in Serbia. Zukorlić is considered the most influential political figure in Sandžak by the director of the Helsinki committee of human rights in Serbia. ${ }^{10}$ During the elections to the minority councils, the BKZ list itself was recognised as a "new political force" (Szöcsik and Bochsler, forthcoming). The BKZ list was supported by two political parties, the freshly founded minority SNP and the state-wide LDP. In the meantime, BKZ has developed into a political party, the Bosniak Democratic Community (Bošnjačka demokratska zajednica, BDZ), founded in December 2010 and headed by Emir Elfić (Ministry for Public Administration and Local Self Government, n.d.), thereby further blurring the lines between minority council competition and political competition more generally. 
Table 1. Hungarian and Bosniak lists for the 2010 NMC elections, leaders, and connections to political parties.

\begin{tabular}{|c|c|c|c|}
\hline Minority & $\begin{array}{l}\text { Lists for NMC elections } 6 \text { June } 2010 \text {, } \\
\text { percentage of votes }\end{array}$ & List headed by & Affiliated political parties \\
\hline \multirow[t]{3}{*}{ Bosniak } & $\begin{array}{l}\text { Bošnjačka kulturna zajednica (BKZ), } \\
\quad 48.4 \%\end{array}$ & $\begin{array}{l}\text { Muftija Muamer ef. } \\
\text { Zukorlić }\end{array}$ & $\begin{array}{l}\text { SNP (Bosniak minority } \\
\text { party) and LDP (state- } \\
\text { wide party) }\end{array}$ \\
\hline & Bošnjačka lista (Bosniak list), 37.35\% & Esad Džudžević & $\begin{array}{l}\text { SDA, BDSS (Bosniak } \\
\text { minority parties) }\end{array}$ \\
\hline & $\begin{array}{l}\text { Bošnjački preporod (Bosniak revival), } \\
14.25 \%\end{array}$ & Nazim Nokić & $\begin{array}{l}\text { SDP (Bosniak minority } \\
\text { party) }\end{array}$ \\
\hline \multirow[t]{5}{*}{ Hungarian } & $\begin{array}{l}\text { Evo ruke za mađarsku zajednicu (Let's } \\
\text { shake hands for the Hungarian } \\
\text { community) } 3.37 \%\end{array}$ & $\begin{array}{l}\text { Zoltán Bunjik and } \\
\text { László Rác } \\
\text { Szabó }\end{array}$ & $\begin{array}{l}\text { GSM (Hungarian minority } \\
\text { party) }\end{array}$ \\
\hline & $\begin{array}{l}\text { Mađarska liga (Hungarian League), } \\
3.31 \%\end{array}$ & Tibor Murenji & LSV (regionalist party) \\
\hline & Pokret mađarske nade (PMN), 2.77\% & Balint Laslo & $\begin{array}{l}\text { PMN (Hungarian minority } \\
\text { party) }\end{array}$ \\
\hline & $\begin{array}{l}\text { Vojvođanski Mađari za Evropu } \\
\text { (Vojvodina Hungarians for Europe), } \\
13.34 \%\end{array}$ & Attila Csengeri & DS (state-wide party) \\
\hline & $\begin{array}{l}\text { Mađarska sloga (Hungarian Unity), } \\
77.21 \%\end{array}$ & Tamas Korhec & $\begin{array}{l}\text { SVM (Hungarian minority } \\
\text { party) }\end{array}$ \\
\hline
\end{tabular}

Table 1 provides an overview of the lists that contested the elections, their affiliations with both ethnic minority and state-wide or regionalist political parties, as well as the results they achieved.

\subsection{NMC elections and campaign strategies}

In terms of the content of the campaign, direct elections politicised the question of who can legitimately represent minorities in Serbian politics, since different minority organisations defended diverse models of minority representation during the campaign and tried to sell their own model as the only legitimate one. Rather than constituting a struggle over the best policy programme in the fields of education and culture, political parties used the minority council elections as a platform to outbid their opponents with regard to the issue of minority representation. The dominant topics during the campaign were: (1) whether the councils can legitimately represent minority interests; (2) whether non-ethnic parties can legitimately represent minority interests; and (3) whether religious leaders can legitimately represent minority interests. The following analysis reveals that the positions occupied by parties and candidates on these three topics can be related to their overall strategy in party competition. As expected by the outbidding model, adopting a more radical stance on the issue of minority representation thereby constituted a particularly attractive alternative for new ethnic parties.

\subsubsection{Legitimacy of the council}

The question whether to participate or not divided minority organisations that challenged the capacity of the NMCs to adequately represent minorities within the state from those that participated in NMCs. Regarding his key reason for boycotting the NMC elections, DSVM leader Ágoston said that the law on the minority councils was not well designed because it did not 
oblige the state authorities to register the voters but left the task to the minority community itself. Furthermore, he criticised attempts of the Democratic Party to be seeking control of the councils by fielding a list that consisted of Hungarian individuals, yet was sponsored by DS. ${ }^{11}$ In a similar vein, DZVM elites accused Belgrade of not preparing the list to the council elections and additionally stated that the concept of pure cultural autonomy fell short of their principal policy aim of territorial autonomy. ${ }^{12}$ Both parties have not changed their policy positions since they were founded. Therefore, it could be hypothesised that they encounter potentially high costs in terms of policy coherence upon participation. In particular, in case of DZVM, accepting cultural autonomy through minority councils could be interpreted as a shift away from the party's more radical principal policy aim of territorial autonomy for the municipalities with a Hungarian majority in the Northern Bačka region.

The Bosniak minority parties that participated in the minority council elections are the two parties that also play the dominant role in Bosniak minority representation in the national parliament. Both SDP and the Bosniak list could reasonably expect to gain influence in the council. Despite their intense competition for the Bosniak vote, they adopt similar positions in favour of cooperation with the state authorities and participated in the governing coalition in Belgrade between 2008 and 2012. Therefore, participation did not require sacrificing policy positions. Both parties had already voted in favour of the law on the minority councils in the Serbian parliament in 2009 and according to both an MP from the Bosniak list and an MP from SDP, both parties are in favour of Bosniak integration into the state and its institutions. ${ }^{13}$

New minority parties generally had high incentives to participate to gain information on their relative power position and at the same time present themselves to the minority electorate for the first time. Consequently, in both minority contexts under observation, new parties that had formed after the most recent parliamentary elections of May 2008 decided to participate, either by fielding their own party list (the Hungarian PMN) or by supporting a list for the council elections, as was the case with Bosniak SNP that supported the BKZ list which was itself soon to develop into a political party. PMN vice-president and minority council candidate Zorán Setyerov exposed this logic clearly, arguing that even though PMN agrees with DSVM leader Ágoston, who boycotted the elections, and that the law on the minority councils has important deficits, PMN decided to participate, taking the first elections since their founding day as an important opportunity to evaluate their electoral potential. ${ }^{14}$

\subsubsection{Representation through non-ethnic parties}

The second level of contestation concerned the question whether non-ethnic parties could also represent the interests of minorities and could and should therefore participate in the NMC elections. On the one hand, ethnic minority parties argued that a minority community should be exclusively represented by an ethnic minority organisation. On the other hand, individual minority community members that prefer to affiliate with a non-ethnic party or organisation argued that these parties can also be legitimate representatives. A number of Hungarians are closely affiliated with either the League of Social Democrats of Vojvodina or the Democratic Party, two non-ethnic, civic parties. According to a Hungarian journalist, if these two parties did not field a list for the NMC elections, Hungarians that do not feel represented by the Hungarian ethnic minority parties - such as SVM, PMN, and GSM - would not have the chance to have a representative of their civic orientation in the council. ${ }^{15}$ For example, in October 2009, 22.3\% of Hungarians surveyed by a public opinion research institute in Vojvodina stated DS as their party of choice, and $8.3 \%$ of Hungarians preferred LSV, which amounts to a total of $30.6 \%$ of surveyed Hungarians who preferred representation through non-ethnic parties in democratic politics, at least outside the minority councils (SCAN Agency 2009, 10). Consequently, ethnic Hungarians decided to stand 
for elections on a list supported by LSV and on a list supported by DS (Table 1). This shows that minority parties not only use minority council elections as an additional arena for intra-ethnic competition, even mainstream, non-ethnic, parties that are successful in gaining votes among the minority in political competition for other offices have incentives to present "their" list during the council elections.

Elites of the ethnically exclusive Hungarian minority parties criticised this representational model as illegitimate. Setyerov, the vice-president of PMN, argued that only the PMN list and the list supported by SVM were legitimate participants of the NMC elections and accused DS and LSV of trying to get access to Hungarian media and Hungarian money through the council. He further differentiated between Hungarians that competed on a minority list and Hungarians on the DS and LSV lists, describing the latter as opportunists who discovered their Hungarian identity only recently: "They earlier declared themselves as Yugoslavs or Serbs, what do I know, they did nothing for the Hungarian minority". ${ }^{16}$

Depending on the rhetoric endorsed by interviewees, Hungarians that competed for LSV and DS in the minority councils thus either help the Serbian state (through Serbian state-wide parties) to take control of the minority councils or provide a legitimate alternative for those Hungarians citizens who do not agree with the dominant ethnic minority party.

Interestingly in the Bosniak case, BKZ, the only list that was supported by a non-ethnic party with its seat in Belgrade, LDP, was also the list that accused its competitors that fielded exclusive minority lists supported exclusively by ethnic minority parties of cooperating too closely with the Serbian state. ${ }^{17}$ A possible explanation for this apparent contradiction is that LDP traditionally enjoys particular support among the Bosniak population ${ }^{18}$ and was in the opposition at the level of the national parliament at the time of the NMC elections. This could explain why it is possible to be simultaneously opposed to cooperation with the state but in favour of cooperating with a state-wide party with its seat in Belgrade. SDP and SDA both have ministers in government, leaving a vacuum for a third, more radical, outbidding party that claims to represent the interests of Bosniaks on the ground, against the central Serbian state in Belgrade, which has precisely been the rhetoric adopted by BKZ (soon to transform into BDZ) in both the minority council and the 2012 general elections (Szöcsik and Bochsler, forthcoming).

\subsubsection{Secular versus religious candidates}

A third level of intra-ethnic division concerns the different representative claims presented by minority organisations. Here, a dividing line can be drawn between those ethnic elites who argue that religion is a part of the cultural identity of the minority and that, hence, religious leaders could and should participate as candidates for the councils, and those ethnic elites who take a secular stance arguing that minority self-government concerns political decision-making and that religious leaders should not participate. This was the most controversial issue in the campaign for the Bosniak NMC but also played a role in the Hungarian one.

The fact that BKZ was headed by a religious leader was seen as highly problematic and perceived as a radical, outbidding move by elites from both SDP and SDA. ${ }^{19}$ Esad Džudžević, who headed the Bosniak list for the council elections differentiated between three models of representing Bosniaks on 6 June 2010, indicating that one of them, the religious option, was "mixed with religious extremism" and therefore "not acceptable at all". ${ }^{20}$ By contrast, BKZ candidate Samir Tandir, who is also spokesperson of the Islamic Community in Serbia, defended religious representation with the argument that Islam was "an inseparable component of the behaviour of the Bosniak nation", and the NMC should therefore be run not only by historians, academics, and party representatives, but also by religious authorities like Zukorlić. ${ }^{21}$ 
In a similar vein, but courting less controversy, the fact that the Hungarian SVM included priests on its list for the Hungarian council elections was criticised by DZVM's vice-president Horváth Ódry. ${ }^{22}$ On the other hand, Maglai Jenő, a member of the SVM executive committee, referred more to a concept of inclusive representation whereby all elites of the Hungarian minority should preferably be brought together on one list and praised the party for including a Catholic, a reformist and an evangelical bishop in an attempt to go beyond presenting a purely political list. ${ }^{23}$

The choice between participation and boycott of minority council elections and, in case of participation, the subsequent choice between various representative claims shows that the question of who represents minorities in institutions of cultural autonomy can therefore be explained with reference to the overall logic of party competition. Of the established organisations, DSVM and DZVM chose to abstain and focused on criticising the status of minority participation in the Serbian state as such. As explained above, in case of DZVM, this can be related to the party's attempt to maintain a coherent policy position with regard to Hungarian autonomy in general party competitions. A party that has been advocating that cultural autonomy is not enough and that Hungarians need to achieve autonomy on an ethno-territorial basis could encounter high costs in terms of maintaining policy coherence were it to consent to the cultural autonomy solution in form of the minority councils. State-wide parties that are popular among minority voters (DS, LSV, and LDP) could participate in the NMC elections with ease because they could draw on the organisational and financial resources of larger, state-wide players. However, they were also easily portrayed as illegitimate representatives and Serbian-sponsored intruders into the minority council by the "real" ethnic minority parties. Ethnic minority parties in Serbia used the NMC elections as an additional arena of competition that was particularly attractive for established minority parties with good chances of winning the elections (SVM, SDP, and the Bosniak list) and newcomers such as PMN and BKZ-BDZ that sought a platform for outbidding established parties with more radical claims.

Pavel Domonji of the Helsinki Committee of Human Rights in Serbia gave perhaps the clearest summary of how BDZ used the NMC elections as a platform for political competition and ethnic outbidding on the issue of Bosniak representation in Serbia, stating that: "He [Zukorlić] sharpened his rhetoric in the election campaign and practically turned the elections into a referendum on which Bosniaks were supposed to choose their future course" (Domonji 2010). The perception of $\mathrm{BKZ}$ as too radical and too closely linked to religion led to neither the list supported by SDA nor the NMC list supported by SDP to agree on forming an NMC governing coalition with Zukorlic's BKZ that won the majority of votes in the council elections. The subsequent decision of the Minister for Human Rights in Serbia to change the decision-making process for electing an NMC executive from simply majority to qualified majority vote (two-thirds of the votes required) meant that the rules applicable to constituting the Bosniak council differed from the rules that were applied to constituting all other minority councils. This unequal treatment by the ministry gave BKZ-BDZ an opportunity to sell its anti-Belgrade stance even more effectively. On 7 July 2010, members of BKZ formed the Bosniak National Council according to the old, simple majority rule and with two members of Bosniak Revival, the list supported by SDP, present, since the presence of an absolute majority of elected members is required to constitute the council. The Serbian authorities did not recognise this council. New elections were to be held in April 2011 - with BKZ rising slogans of boycott - but were postponed (Balkaninsight, March 31, 2011).

\section{Conclusion}

This article has examined the first direct elections to minority councils in Serbia. On the basis of evidence from field research, it has been argued that minority council elections reflect the situation 
of intra-ethnic competition and provide an additional arena for ethnic outbidding in particular for new ethnic parties. In all but one of the 16 minority council election campaigns in Serbia, several representational models were offered to minority voters. This should be welcomed from the perspective of democratic pluralism, since it allows minority members to express diverse preferences as well as establish elite accountability through alternation based on party competition (Szöcsik and Bochsler, forthcoming). However, this would require programmatic competition over the actual policy issues at stake in the minority council: education, language use, culture and information in the minority language. In the Serbian case, direct elections to minority councils have, instead, provided a further arena for intra-ethnic political competition more generally and have also provided a platform in particular for new ethnic parties to outbid their opponents with regard to the issue of minority representation.

Furthermore, minority council elections may not only reflect, but in the long run can be expected to also affect, the patterns of political competition for minority votes. Control of the councils implies control of the minority media and control over a range of offices related to the maintenance of culture, such as whom to employ as teachers, librarians, or editors of newspapers in the minority language. Maglai Jenö, member of the SVM executive committee, criticised the DS attempt to get their foot into the Hungarian minority council, but he did so with a telling statement that can be applied to any party that gains control of the minority council: "Whoever gets to control the national council will be controlling the community". ${ }^{24}$ According to a Hungarian journalist, media institutions within minority communities still depend to a large extent on the political parties of national minorities. ${ }^{25}$ Asked whether given the results of the Hungarian council elections SVM now had an advantage over other Hungarian parties, Vojvodina analyst Alexander Popov answered: "Of course this package of control (kontrolni paket) in the national council will give additional wings to this party" (cited Politika, June 8, 2010). This could provide an interesting avenue for future research that could trace the electoral fortunes of council-dominating parties over time. Some first comparative evidence can be found in Szekely (2011), who shows how already at an earlier stage, namely when debating the exact design of cultural autonomy institutions, dominant Hungarian minority parties in Serbia and Romania have tried to suggest the institutional design that will most likely prevent them from being challenged by rival parties in intra-ethnic competition.

Further comparative case studies of minority councils are now needed to see whether the explorative insights gained from the "hypothesis-building case study" presented here stand up to empirical tests (Rohlfing 2012, Chapter 1). Nonetheless, some normative implications can be considered already at this stage. Following Saward who theorises representation as a dynamic relationship of claim-making (on part of the representative) and claim-acceptance (on part of the represented), the legitimacy of representative claims (such as: "our organisation represents the interests of the Hungarian minority in Serbia") can only be properly assessed by those being represented under the conditions of an open society, where independent media ensures that citizens gain enough information to recognise who makes representative claims, judge how well founded they are, and decide for themselves whether they respond by accepting or rejecting these claims (Saward 2010, Chapter 6). This condition for legitimate representation can be undermined within minority communities if one minority organisation gains full control of the council and consequently the minority media. ${ }^{26}$ Minority councils are adopted to enhance the stability of inter-ethnic democracy as they enable minorities to decide on cultural politics independently from the central state authorities, which in Serbia predominantly represent the Serbian ethnic majority group. Yet, they can at the same time stand against intra-ethnic democracy, privileging status quo elites and baring those minority members who do not affiliate with the dominant minority party permanently from representation. 


\section{Acknowledgments}

Field research in Serbia was financially supported by the German Academic Exchange Service (DAAD). We thank Christian Blum and two anonymous referees as well as one of the editors for very helpful comments and all interview partners for sharing their time and experience.

\section{Notes}

1. The insights about the diversity of representative claims presented in this article were gained predominantly from interviews with minority elites. The analysis therefore exemplifies only one of the possible manifestations of representative claims voiced during the campaigns for the minority council elections, i.e. the claims brought forward by political elites during interviews (and not, for example, within the minority media). We hope that future research will contribute additional perspectives. Audio recordings and transcripts of all interviews cited in this article are in the authors' possession. The interview guidelines are available upon request. Interviewees gave their consent to having their names published.

2. It should be noted, however, that the exact nature of these rights remains contested and that the European Union has applied differentiated standards during the past accession of the Central and Eastern European countries (Schwellnus 2005). A detailed discussion of the contested meaning of minority rights in European norms and in Western and Eastern Europe respectively is beyond the scope of this article, but we refer the reader to Deets' (2006) thorough treatment of this topic.

3. An English translation of the Law on National Councils is provided by the European integration office of the government of the Republic of Serbia and can be found at: http://www.seio.gov.rs/upload/ documents/ekspertske\%20misije/protection_of_minorities/law_on_national_councils.pdf [Accessed May 14, 2012]. All direct citations from the law draw on this translation.

4. According to Lijphart (1977), the consociational model of democracy consists of the following characteristics: grand coalition of elites representing all segments of the society; segmental autonomy; mutual veto right enjoyed during the decision-making process by the representatives of each societal segment; proportionality as a principle guaranteeing representation of the groups in the executive, legislative and state administration. With regard to these features, Bosnia and Herzegovina represent the consociational model, although it lacks the basic understanding between the segmental leaders concerning the shape of the state. The system is similar to the federal system of Belgium, where there is territorial and national division (Bieber 1999). Power sharing between the key groups is reflected in the composition of all state institutions as well as in the legislative procedure and judicial review.

In comparison, minorities in Kosovo's political regime have more limited opportunities and therefore the Kosovo political system is consociation-like with many examples of power sharing. For example positive discrimination tools exist, especially in the Assembly of the Republic of Kosovo. Power sharing in the executive is guaranteed constitutionally. Adopting a law in the areas of vital interest to ethnic communities requires the consent of a majority of these representatives. The Constitution also guarantees minority participation in the judicial system at all levels.

Amended on the basis of the Framework Agreement of 2001, the Constitution of the Republic of Macedonia contains several provisions related to the participation of minorities in state governance. The constitution recognises citizens of ethnic origins other than the Macedonian majority and secures their rights through a minority veto in parliament. Bieber $(2008,13)$ refers to this as a "minimalist consociational system". In the case of Macedonia, where executive power sharing is not legally guaranteed, a practical consensus on the need to include Albanians in governing coalitions has, however, formed over the years, rendering the Macedonian power-sharing system more flexible than the Bosnian one.

5. Minority organisations are defined by the law in the following way: "Any organization, association or political organization that incorporates in its name a designation of one national minority, or whose statute designates it as an organization or an association or a political organization that gathers or acts in the interests of persons belonging to a national minority, shall be considered an organization, association or political organization of a national minority" (Article 101, Law on National Councils).

6. Author's interview with Maglai Jenő, 6 June 2010, Subotica. The most recent census has been conducted in 2011. At the time of writing, only preliminary results had been published by the Serbian statistical office and these did not contain information on nationality (Republika Srbija - Republički zavod za statistiku 2011).

7. Author's interview with Attila Marton, 2 June 2010, Novi Sad.

8. Sandžak is an old Ottoman term for an administrative unit that is smaller than a province but larger than a municipality. 
9. Out of these, the 19,000 Muslims by nationality are of Slavic origin and identify themselves for various reasons neither as Bosniaks, nor as Sandžaklija (in English: inhabitants of Sandžak), neither as Montenegrin, nor as Serbian Muslims.

10. Author's interview with Sonja Biserko, 5 May 2010, Belgrade. Two parallel Islamic communities exist in Serbia. The Islamic community of Serbia is headed by Adem Zilkić and has its seat in Belgrade. The Islamic community in Serbia is headed by Muamer Zukorlić, has its seat in Novi Pazar, and is oriented towards Sarajevo. For more details, see Morrison (2008).

11. Author's interview with Andras Ágoston, 7 June 2010, Temerin.

12. Author's interview with Esad Džudžević, 6 May 2010, Belgrade, and with Munir Poturak, 4 May 2010, Belgrade.

13. See Note 12.

14. Author's interview with Zorán Setyerov, 3 June 2010, Subotica.

15. Author's interview with Attila Marton, 2 June 2010, Novi Sad.

16. See Note 14.

17. Author's interview with Samir Tandir, 17 May 2010, Novi Pazar.

18. In the first round of the presidential elections of 2008, LDP candidate Cedomir Jovanović received his highest support in the Raška district (8.49\% of valid votes), which includes the Bosniak majority municipalities of Novi Pazar and Tutin and in the Zlatibor district ( $8.19 \%$ of valid votes), which includes the Bosniak municipalities of Sjenica, Nova Varoš, Prijepolje and Priboj. His national aggregate result in the first round was 5.34\% (Republika Srbija - Republički zavod za statistiku 2008).

19. Author's interview with Esad Džudžević, 6 May 2010, Belgrade.

20. See Note 19.

21. Author's interview with Samir Tandir, 17 May 2010, Novi Pazar.

22. Author's interview with Márta Horváth Ódry, 10 June 2010, Sombor.

23. Author's interview with Maglai Jenő, 6 June 2010, Subotica.

24. See Note 23.

25. Author's interview with Attila Marton, 2 June 2010, Novi Sad.

26. Of course, this does not follow by necessity. If democratic principles and the norms of an open society are rooted deeply enough in the behaviour of minority elites, the chances of creating many sources of media presenting different viewpoints and political perspectives may be higher than our conclusions drawn on the basis of minority communities in Serbia would suggest.

\section{Notes on contributors}

Christina Isabel Zuber is a $\mathrm{PhD}$ candidate and research associate at the Chair of Comparative Politics, University of Cologne, Germany. Her past research has dealt with asymmetrical federalism and separatism in Russia and ethnic party competition in Serbia. Her articles have appeared in Comparative Political Studies and Party Politics.

Jan Jakub Muś works as an Assistant Professor at the Catholic University of Lublin and Warsaw School of Social Sciences and Humanities. In 2011, he obtained his PhD degree from the University of Maastricht. He specialises in the contemporary politics, constitutional developments and history of the Balkan countries.

\section{References}

Agranoff, R. ed. 1999. Accommodating Diversity: Asymmetry in Federal States. Baden-Baden: Nomos.

Bieber, F. 1999. "Consociationalism - Prerequisite or Hurdle for Democratisation in Bosnia? The Case of Belgium as a Possible Example." South East Europe Review 2 (3): 79-94.

Bieber, F. 2008. "Power-Sharing and the Implementation of the Ohrid Framework Agreement." In Power Sharing and the Implementation of the Ohrid Framework Agreement, edited by Friedrich Ebert Stiftung, 7-40. Skopje: Friedrich Ebert Stiftung. Accessed January 24, 2011. http://www.fes.org.mk/ pdf/OFA_english.pdf

Chandra, K. 2005. "Ethnic Parties and Democratic Stability." Perspectives on Politics 3 (2): 235-252.

Chandra, K. 2011. "What is an Ethnic Party? Party Politics 17 (2): 151-169.

Constitution of the Republic of Serbia. 2006. Accessed January 16, 2012. http://www.srbija.gov.rs/ cinjenice_o_srbiji/ustav.php

Deets, S. 2006. "Reimagining the Boundaries of the Nation: Politics and the Development of Ideas of Minority Rights." East European Politics \& Societies 20 (3): 419-446. 
Deets, S., and S. Stroschein. 2005. "Dilemmas of Autonomy and Liberal Pluralism: Examples Involving Hungarians in Central Europe." Nations and Nationalism 11 (2): 285-305.

Domonji, P. 2010. "National Minority Councils Elected. Minorities more Reliable than the State." Helsinki Charter, nos. 139-140: 1-3. Accessed May 16, 2012. http://www.helsinki.org.rs/hcharter t30a04.html

Eberhardt, P. 2003. Ethnic Groups and Population Changes in Twentieth-Century Central-Eastern Europe: History, Data, and Analysis. New York: M.E. Sharpe.

European Council in Copenhagen. 21-23 June 1993. Conclusions of the Presidency, SN 180/1/93 REV 1. Accessed January 16, 2012. http://ec.europa.eu/bulgaria/documents/abc/72921 en.pdf

Framework Agreement (Ohrid Agreement) Concluded in Skopje. 13 August 2001. Āccessed February 3, 2011. http://www.venice.coe.int/docs/2001/CDL\%282001\%29104-e.pdf

Gojković, N. 2009. "System of Minorities' Protection in Serbia." Lecture given at Konrad Adenauer Foundation, Belgrade, February 22. Accessed February 3, 2012. http://www.kas.de/upload/auslands homepages/serbien/Gojkovic_en.pdf

Horowitz, D. L. 1985. Ethnic Groups in Conflict. Berkeley, CA: University of California Press.

Kocsis, K., and E. Kocsisné Hodosi. 1998. Ethnic Geography of the Hungarian Minorities in the Carpathian Basin. Hungary: Simon Publications LLC. Accessed January 31, 2012. http://www.hungarianhistory. $\mathrm{com} / \mathrm{lib} / \mathrm{hmcb} /$

Kymlicka, W. 1998. "Is Federalism a Viable Alternative to Secession?" In Theories of Secession, edited by P. Lehning, 111-150. London: Routledge.

Lijphart, A. 1977. Democracy in Plural Societies. A Comparative Exploration. New Haven, CT: Yale University Press.

Lijphart, A. 1989. "Democratic Political Systems: Types, Cases, Causes, and Consequences." Journal of Theoretical Politics 1 (1): 33-48.

Ministry for Public Administration and Local Self Government. n.d. "Izvod iz Registra političkih stranaka." Accessed July 5, 2010. http://www.drzavnauprava.gov.rs/pages/article.php?id=1698

Ministry of Human and Minority Rights of the Republic of Serbia. 2010. "Zvanični rezultati izbora za nacionalne savete nacionalnih manjina 2010.” Accessed December 23, 2010. http://izbori.ljudskaprava.govrs/ $\mathrm{sr} /$ info/story/75/Zvanični + rezultati+izbora+za+nacionalne+savete+nacionalnih + manjina $+2010 . \mathrm{html}$

Morrison, K. 2008. Political and Religious Conflict in the Sandžak, Defence Academy of the United Kingdom, Balkans Series 13. Shrivenham: Conflict Studies Research Centre.

Nimni, E. 1999. "Nationalist Multiculturalism in Late Imperial Austria as a Critique of Contemporary Liberalism: The Case of Bauer and Renner." Journal of Political Ideologies 4 (3): 289-314.

Nimni, E. 2007. "National-Cultural Autonomy as an Alternative to Minority Territorial Nationalism." Ethnopolitics 6 (3): 345-364.

Rabushka, A., and K. A. Shepsle. 1972. Politics in Plural Societies: A Theory of Democratic Instability. Columbus, OH: Charles E. Merrill.

Republika Srbija - Republički zavod za statistiku. 2003. Popis stanovnistva, domačinstava i stanova u 2002. Stanovništvo - knjiga 3 - Veroispovest, maternji jezik i nacionalna ili etnička pripadnost prema starosti i polu (podaci po opštinama). Belgrade. Accessed January 30, 2012. http://webrzs.stat.gov.rs/axd/Zip/ VJN3.pdf

Republika Srbija - Republički zavod za statistiku. 2008. Predsednički izbori januar 2008. Accessed July 1, 2010. http://webrzs.stat.gov.rs/axd/IzboriPDF/KonacniWCJ.pdf

Republika Srbija - Republički zavod za statistiku. 2011. Popis stanovnistva, domačinstava i stanova $u$ Republici Srbiji 2011. Prvi rezultati. Belgrade. Accessed January 31, 2012. http://media.popis2011. stat.rs/2011/prvi-rezultati.pdf

Rohlfing, I. 2012. Case Studies and Causal Inference: An Integrative Framework. Basingstoke: Palgrave Macmillan.

Saward, M. 2010. The Representative Claim. Oxford: Oxford University Press.

SCAN Agency for Research and Development (in Serbian: SKAN Agencija za istraživanja i razvoj d.o.o.). 2009. Istraživanje javnog mnenja, Vojvodina oktobar 2009. Stranačke preferencije. Stavovi o nadležnostima Vojovodine. Novi Sad. Aggregate results of the survey were provided by Milka Puzigaća, director of the SCAN Agency and are available from the authors upon request.

Schwellnus, G. 2005. "The Adoption of Non-discrimination and Minority Protection Rules in Romania, Hungary and Poland." In: The Europeanization of Central and Eastern Europe, edited by F. Schimmelfennig and U. Sedelmeier, 51-70. Ithaca, NY: Cornell University Press.

Sisk, T. D. 1996. Power Sharing and International Mediation in Ethnic Conflicts. Washington, DC: United States Institute of Peace. 
Stroschein, S. 2003. "What Belgium Can Teach Bosnia: The Uses of Autonomy in Divided House States." Journal on Ethnopolitics and Minority Issues in Europe, 3: 1-30.

Szekely, I. G. 2011. "The Issue of Personal Autonomy in Romania and Serbia: A Comparative Analysis of Minority Visions and Divisions." Paper presented at the seminar of the Center for the Study of Imperfections in Democarcy of the Central Eastern University, Budapest, October 17.

Szöcsik, E., and D. Bochsler. Forthcoming. "All Jointly or Everyone on its Own? On Fissions and Fusions of Ethnic Minority Parties." In New Nation-States and National Minorities, edited by J. Danero Iglesias, N. Stojanović and S. Weinblum, 233-256. Colchester: ECPR Press.

Vermeersch, P. 2010. "Minority Associations. Issues of Representation, Internal Democracy, and Legitimacy." In Political Participation of Minorities: A Commentary on International Standards and Practice, edited by M. Weller and K. Nobbs, 682-701. Oxford: Oxford University Press.

Zakon o Nacionalnim Savetima Nacionalnih Manjina [Law on National Councils of National Minorities]. 2009. "Službeni Glasnik Republike Srbije br. 72/2009." Accessed November 18, 2010. http://www. parlament.gov.rs/content/cir/akta/akta_detalji.asp? $I d=681 \& \mathrm{t}=\mathrm{Z}$

Zuber, C. I. 2011a. "Understanding the Multinational Game: Toward a Theory of Asymmetrical Federalism." Comparative Political Studies 44 (5): 546-571.

Zuber, C. I. 2011b. "Beyond Outbidding? Ethnic Party Strategies in Serbia." Party Politics, published online July 25, 2011. doi:10.1177/1354068811410368.

Appendix. Overview on the minority council elections in Serbia, 6 June 2010

\begin{tabular}{|c|c|c|}
\hline $\begin{array}{l}\text { Minority (no. of } \\
\text { lists) }\end{array}$ & Lists and election results in the NMC elections of 6 June 2010 & Turn-out (\%) \\
\hline$\overline{\text { Czechs (1) }}$ & Ćesi zajedno $100 \%$ & 46.52 \\
\hline Albanian (2) & $\begin{array}{l}\text { Demokratska unija albanaca } 18.97 \% \\
\text { Partija za demokratsko delovanje Riza Halimi } 81.03 \%\end{array}$ & 56.31 \\
\hline Greek (2) & $\begin{array}{l}\text { Helenizam uz Srpstvo - Vera Jeftimijades Jobst } 34.62 \% \\
\text { Volim te - SaGaPo Smederevo } 65.38 \%\end{array}$ & 77.05 \\
\hline Egyptian (2) & $\begin{array}{l}\text { Budućnost } 60.09 \% \\
\text { Egipćani ali zajedno } 39.91 \%\end{array}$ & 44.93 \\
\hline German (2) & $\begin{array}{l}\text { Podunavski Nemci Vojvodine } 29.47 \% \\
\text { Zajedno za jedinstvo Nemačke nacionalne manjine Srbije } 70.53 \%\end{array}$ & 63.73 \\
\hline Bosniak (3) & $\begin{array}{l}\text { Bošnjačka kulturna zajednica - BKZ - Muftija Muamer ef. Zukorlić } \\
\quad 48.4 \% \\
\text { Bošnjačka lista } 37.35 \% \\
\text { Bošnjački preporod } 14.25 \%\end{array}$ & 56.46 \\
\hline Ashkali (3) & $\begin{array}{l}\text { Zajedno } 37.13 \% \\
\text { Aškalije za spas, mir i budućnost } 51.25 \% \\
\text { Aškalije za bolje sutra - Zijadin Calihi } 11.62 \%\end{array}$ & 38.85 \\
\hline Hungarian (5) & $\begin{array}{l}\text { Evo ruke za mađarsku zajednicu - Zoltan Bunjik i Laslo Rac Sabo } \\
\quad 3.37 \% \\
\text { Mađarska liga - Dr Murenji Tibor } 3.31 \% \\
\text { Pokret mađarske nade Laslo Balint } 2.77 \% \\
\text { Vojvođanski Mađari za Evropu Dr Cengeri Atila } 13.34 \% \\
\text { Mađarska sloga } 77.21 \%\end{array}$ & 55.46 \\
\hline Slovak (5) & $\begin{array}{l}\text { Slovenska strana } 8.02 \% \\
\text { Nova Slovačka Stranka } 5.37 \% \\
\text { Slovačka liga } 4.55 \% \\
\text { Matica Slovačka Za Slovački identitet } 22.36 \% \\
\text { Slovaci zajedno Ana Tomanova Makanova } 59.70 \%\end{array}$ & 46.81 \\
\hline
\end{tabular}


Appendix. Continued

\begin{tabular}{|c|c|c|}
\hline Rusyn (6) & $\begin{array}{l}\text { Sremačka lista } 10.08 \% \\
\text { Matica rusinska } 11.24 \% \\
\text { Rusinska omladina Saša Paljenkaš } 7.62 \% \\
\text { Zajedno za Rusine Slavko Rac } 36.03 \% \\
\text { Rusinska demokratska stranka }- \text { Za narod svoj } 9.50 \% \\
\text { Rusinska liga Oleha Papuga - } 25.53 \%\end{array}$ & 56.07 \\
\hline Romanian (6) & $\begin{array}{l}\text { Ujedinjeni Rumuni - Raša Todorel } 6.18 \% \\
\text { Ujedinjeni Rumuni iz Srbije - Vasile Barbu 7.12\% } \\
\text { Zajednica Rumuna u Srbiji } 15.42 \% \\
\text { Jedinstvo } 14.82 \% \\
\text { Rumunsko jedinstvo za evropsku budućnost - Daniel Petrović } 48.14 \% \\
\text { Nezavisni Rumuni } 8.33 \%\end{array}$ & 54.45 \\
\hline Ukrainian (7) & $\begin{array}{l}\text { Grupa građana Dalibor Pjekni 5.98\% } \\
\text { Pravda } 17.74 \% \\
\text { Ukrajinska lista - za budućnost } 24.82 \% \\
\text { Galicijani } 4.21 \% \\
\text { Kalina - Petar Zakamarok } 9.57 \% \\
\text { Proleće - Vesna } 21.59 \% \\
\text { "Kolomejka" Sremska Mitrovica Ana Ljahović } 16.1 \%\end{array}$ & 60.72 \\
\hline Bulgarian (7) & $\begin{array}{l}\text { Liberalna zajednica Bugara } 4.55 \% \\
\text { Za Bosilegrad i evropsku Srbiju 13.47\% } \\
\text { Bugarska nacionalna manjina u Srbiji - Dragoljub Notev 5.5\% } \\
\text { Za nas Bosilegrad Vladimir Zaharijev 27.84 } \\
\text { Da se složimo - Siniša Randelov 3.91\% } \\
\text { Bugarska zajednica za Evropsku Srbiju - Zoran Petrov 30.07\% } \\
\text { Koalicija Bugara u Srbiji Nebojša Ivanov 14.64\% }\end{array}$ & 66.04 \\
\hline Bunjevac (7) & $\begin{array}{l}\text { Jugoslovenski Bunjevci } 8.32 \% \\
\text { Bunjevačka liga - Buljovčić Stipan, Bunjo 7.02\% } \\
\text { Bunjevci za Bunjevce - Nikola Babić 14.55\% } \\
\text { Savez bačkih Bunjevaca - Mirko Bajić } 15.02 \% \\
\text { Bunjevačka narodna lista - Branko Pokornić } 12.57 \% \\
\text { Bunjevačka lista za evropsku Srbiju 8.32\% } \\
\text { Sad i uvik - samo Bunjevci - mr Suzana Kujundzić Ostojić 34.18\% }\end{array}$ & 41.52 \\
\hline Vlach (9) & $\begin{array}{l}\text { Autentični Vlasi - Dragoljub Firulović } 1.18 \% \\
\text { Vlasi u Srbiji - Svoji na svome } 1.58 \% \\
\text { Vlasi za evropsku Srbiju - prim. dr. Siniša Čelojević 14.8\% } \\
\text { Vlasi opštine Zajecar - Miodrag Marković } 4.46 \% \\
\text { Ujedinjeni Vlasi - Dragan Balašević } 11.74 \% \\
\text { Vlasi u evropskoj Srbiji - Neli Đorđević } 10.72 \% \\
\text { Lista za Vlahe u Srbiji - Centar za ljudska prava i interetničku } \\
\quad \text { toleranciju - Bor 1.21\% } \\
\text { Zajednica Vlaha Srbije - dr. Predrag Balašević } 27.93 \% \\
\text { Vlasi za Srbiju - Srbija za vlahe, Miletić mihajlović - Tica 26.38\% }\end{array}$ & 46.62 \\
\hline Roma (10) & $\begin{array}{l}\text { Romi za evropsku Srbiju } 44.9 \% \\
\text { Romi Srbije Memišević - Milanović } 0.87 \% \\
\text { Ujedinjeni Romi Miša Stojkov - Milan Nikolić } 2.09 \% \\
\text { Grupa građana Roma Srbije - Dragiša Todorović } 8.77 \% \\
\text { Romska lista za centralnu Srbiju - Nikolić Božidar 1.57\% } \\
\text { Internacionalna Romska Unija Srbije za bolje Sutra 2.16\% } \\
\text { Savez društava Roma pčinjsko jablanički okrug } 15.06 \% \\
\text { Romski glas za Evropu 3.89\% } \\
\text { Vojvođanska romska lista Petar Nikolić } 13.67 \% \\
\text { Romska partija Srđan Sajn } 7.03 \%\end{array}$ & 54.95 \\
\hline
\end{tabular}

Source: Compiled on the basis of the official results of the NMC elections of June 2010, Ministry of Human and Minority Rights of the Republic of Serbia (2010). 